\title{
Nutrients and sediment in frozen-ground runoff from no-till fields receiving liquid- dairy and solid-beef manures
}

\author{
M.J. Komiskey, T.D. Stuntebeck, D.R. Frame, and F.W. Madison
}

\begin{abstract}
Nutrients and sediment in surface runoff from frozen agricultural fields were monitored within three small (16.0 ha [39.5 ac] or less), adjacent basins at a no-till farm in southwest Wisconsin during four winters from 2003 to 2004 through 2006 to 2007. Runoff depths and flow-weighted constituent concentrations were compared to determine the impacts of surface-applied liquid-dairy or solid-beef manure to frozen and/or snow-covered ground. Despite varying the manure type and the rate and timing of applications, runoff depths were not significantly different among basins within each winter period. Sediment losses were low (generally less than $22 \mathrm{~kg} \mathrm{ha}^{-1}\left[20 \mathrm{lb} \mathrm{ac}^{-1}\right]$ in any year) and any statistical differences in sediment concentrations among basins were not related to the presence or absence of manure or the amount of runoff. Concentrations and losses of total nitrogen and total phosphorus were significantly increased in basins that had either manure type applied less than one week preceding runoff. These increases occurred despite relatively low application rates. Lower concentrations and losses were measured in basins that had manure applied in fall and early winter and an extended period of time (months) had elapsed before the first runoff event. The highest mean, flow-weighted concentrations of total nitrogen $\left(31.8 \mathrm{mg} \mathrm{L}^{-1}\right)$ and total phosphorus $\left(10.9 \mathrm{mg} \mathrm{L}^{-1}\right)$ occurred in winter 2003 to 2004 , when liquid-dairy manure was applied less than one week before runoff. On average, dissolved phosphorus accounted for over $80 \%$ of all phosphorus measured in runoff during frozen-ground periods. The data collected as part of this study add to the limited information on the quantity and quality of frozen-ground runoff at field edges, and the results highlight the importance of manure management decisions during frozen-ground periods to minimize nutrients lost in surface runoff.
\end{abstract}

Key words: edge-of-field—manure-nutrients—sediment—snowmelt

\begin{abstract}
The surface application of manure to frozen and/or snow-covered cropland soils is a common practice on livestock farms located in midlatitude, continental-climate regions. The frozen-ground period (FGP) provides an opportunity to haul manure with minimal soil compaction, reduces the volume of manure storage required, and can increase the time available for field preparation and planting in the spring. One alternative to spreading manure during the FGP is to have adequate manure storage; however, storage compresses the time available for spreading, increases capital investment, and can pose potential environmental problems when leaks or failures occur (Kongoli and Bland 2002).
\end{abstract}

Limited studies (most predating 1980) have evaluated both the quality and quantity of surface runoff from areas receiving surface-applied manure during FGPs. A review of some of these studies showed substantial nutrient losses due to wintertime manure application (Srinivasan et al. 2006). However, some studies suggest that the application of manure to frozen and/or snow-covered soils can have no or minimal effects (Ginting et al. 1998; Young and Holt 1977) or can potentially reduce nutrient losses by reducing the volume of runoff (Kongoli and Bland 2002). It is difficult to determine exactly why varying conclusions could be made; however, there is a variety of differences in the way the studies were conducted. Some of these differences included, but were not limited to the means by which runoff was generated (snowmelt only versus rain on snowmelt) and the management style and on-farm conditions (manure amount, type of manure, application timing, tillage, field residue, soil type and texture, and slope) during the monitoring periods.

Studies have also suggested that the timing of manure applications during FGPs can influence nutrients exported in runoff. However, these studies also show conflicting results. Klausner et al. (1976) suggested that applying manure prior to snow reduces nutrients lost compared to applying manure during snowmelt, whereas Young and Mutchler (1976) showed that applying manure on top of snow keeps manure and associated nutrients out of snowmelt flow paths. Despite limited and conflicting study results, the application of manure during the FGP has been shown to have adverse effects on aquatic resources if the applied manure enters water bodies (Milne 1976; Young and Mutchler 1976; Madison et al. 1998). Most states have developed guidelines for manure management during FGPs (Srinivasan et al. 2006). These guidelines vary from state to state and have been revised and updated as more information is available.

The agricultural management practice of no-till has been promoted as a way to reduce nutrients and sediments lost in surface runoff. Most studies have shown reduced runoff volume and sediment loss from no-till fields during unfrozen conditions, compared to conventionally-tilled fields (Mickelson et al. 2001; Cox and Hendricks 2000; Andraski et al. 1985). However, limited roughness in no-till fields can potentially lead to increased runoff and nutrient losses during FGPs. Young and Mutchler (1976) showed that no-till practices posed more of a threat to nutrient losses on frozen soils than conventional tillage because the field surface is relatively smooth and nutrients accumulate at the soil surface. Hansen et al. (2000) found that this surface accumulation resulted in greater soluble phosphorus $(\mathrm{P})$ losses in snowmelt runoff.

Matthew J. Komiskey and Todd D. Stuntebeck are physical scientists with the US Geological Survey at the Water Science Center in Middleton, Wisconsin. Dennis R. Frame and Fred W. Madison are codirectors of the Discovery Farms Program, a University of Wisconsin-Extension program, in Pigeon Falls, Wisconsin. 
In response to limited data and conflicting literature results available regarding wintertime runoff from no-till fields and the effects of manure applied during FGPs, research was conducted at a privately owned livestock farm. Surface runoff quantity and quality data from runoff events were collected over a four-year period to quantify runoff losses, the timing of these losses, and the conditions in which losses typically occurred. The runoff results, in addition to the manure-application data, were then used to evaluate the impacts of applying liquid-dairy or solid-beef manure to frozen and/or snow-covered ground.

\section{Materials and Methods}

Site Description. The US Geological Survey, in cooperation with the University of Wisconsin Discovery Farms program, installed three surface monitoring stations in grassed waterways within three small $(6.8,7.0$, and 16.0 ha $[16.9,17.2$, and $39.5 \mathrm{ac}])$, adjacent basins at a privately owned farm in southwest Wisconsin (figure 1). Each basin contained portions of two separate farm fields with $4 \%$ to $6 \%$ average slope. Field soils consisted of primarily Tama silt loam (Fine-silty, mixed, superactive, mesic Typic Argiudoll) overlying fractured limestone bedrock. The soils had not been tilled for approximately twenty years. Soil properties $-\mathrm{pH}$, organic matter, and soil test $\mathrm{P}$ values (Bray-1 method)were similar among basins (table 1). Average soil test $\mathrm{P}$ values were approximately 80 ppm $\left(160 \mathrm{lb} \mathrm{ac}^{-1}\right)$ in each basin. Fields were planted on the contour in a rotation of two years of corn (Zea mays L.) followed by one year of soybeans (Glycine max L.). Terraces and grassed waterways were used as conservation practices to reduce soil erosion and move runoff water from the field. Corn was harvested as silage or grain, with about twothirds of corn-grain residue removed for livestock bedding for a beef-finishing enterprise. Solid-beef manure (SBM) from the farm and liquid-dairy manure (LDM) from a neighboring confined-dairy farm were periodically surface applied to the cropped fields to meet nutrient requirements.

Monitoring stations were installed, maintained, and operated according to the methods described in Stuntebeck et al. (2008). H-flumes were used to quantify the volume of runoff, while refrigerated samplers collected discrete, time-based samples during natural rainfall- and/or snowmelt-induced runoff events. Samples were generally

\section{Figure 1}

Monitoring locations, basin sizes, and field locations at a no-till farm in southwest Wisconsin.

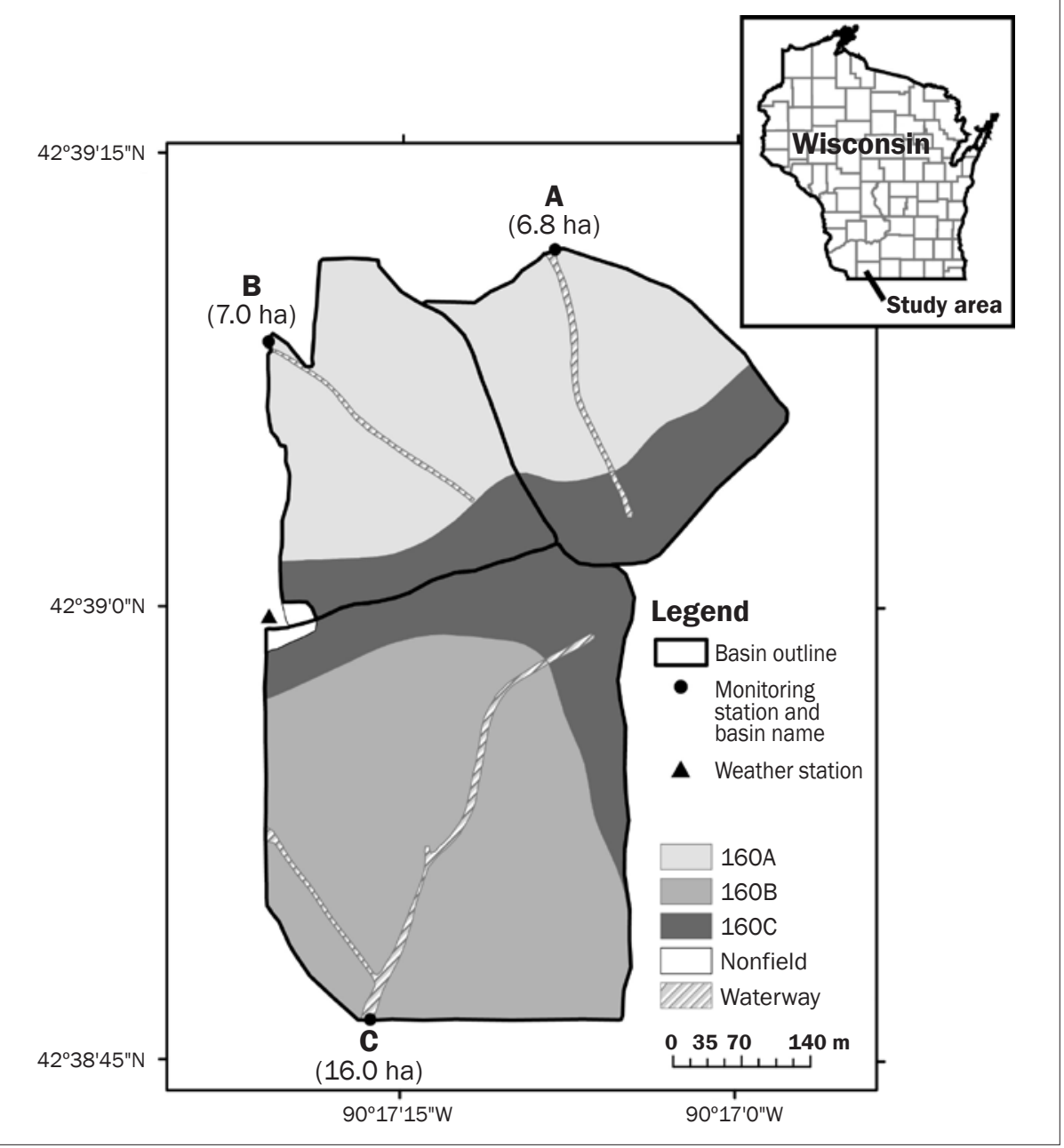

Table 1

Soil properties of Tama silt loam for three monitored basins located at a no-till farm in southwest Wisconsin, sampled October 2006.

\begin{tabular}{|c|c|c|c|c|}
\hline $\begin{array}{l}\text { Basin } \\
\text { name }\end{array}$ & $\begin{array}{l}\text { Sample } \\
\text { depth }(\mathrm{cm})\end{array}$ & Soil pH & $\begin{array}{l}\text { Soil organic } \\
\text { matter (\%) }\end{array}$ & $\begin{array}{l}\text { Soil phosphorus } \\
\text { (ppm) }\end{array}$ \\
\hline \multicolumn{5}{|l|}{ A } \\
\hline & 0 to 2.5 & 7.1 & 4.8 & 142 \\
\hline & 2.5 to 15.2 & 7.3 & 3.4 & 83 \\
\hline & 0 to 15.2 & 7.2 & 3.6 & 97 \\
\hline & 15.2 to 30.5 & 7.2 & 2.7 & 25 \\
\hline \multicolumn{5}{|l|}{ B } \\
\hline & 0 to 2.5 & 7.0 & 4.5 & 143 \\
\hline & 2.5 to 15.2 & 7.0 & 3.4 & 86 \\
\hline & 0 to 15.2 & 7.0 & 3.4 & 82 \\
\hline & 15.2 to 30.5 & 7.1 & 2.8 & 56 \\
\hline \multicolumn{5}{|l|}{$\overline{\mathbf{C}}$} \\
\hline & 0 to 2.5 & 7.0 & 4.5 & 102 \\
\hline & 2.5 to 15.2 & 7.2 & 3.4 & 48 \\
\hline & 0 to 15.2 & 7.2 & 3.8 & 82 \\
\hline & 15.2 to 30.5 & 7.3 & 2.8 & 20 \\
\hline
\end{tabular}


retrieved within 24 hours of the end of a runoff event and were subsequently iced and transported to the Water and Environmental Analysis Laboratory at the University of Wisconsin-Stevens Point.

A weather station on the farm collected weather and soil temperature data (figure 1). Measurements included rainfall amount and intensity, soil temperature at 2, 5, 10, 20, 40, and $80 \mathrm{~cm}(0.8,2.0,3.9,7.9,15.7$, and 31.5 in), and air temperature. Frozen precipitation (snow, ice pellets, and hail) was estimated using data from the National Weather Service station in Platteville, Wisconsin, approximately $18.2 \mathrm{~km}(11.3 \mathrm{mi})$ to the northeast (National Weather Service 2007). Annual rainfall (1971 to 2000) averages $917 \mathrm{~mm}$ (36.1 in), and snowfall averages $1,041 \mathrm{~mm}$ (41.0 in) at this weather station (Midwestern Regional Climate Center 2007a; Midwestern Regional Climate Center 2007b).

Volumes were measured for all runoff events, and water samples were collected and analyzed for most runoff events for the entire period from November 2003 through September 2007; however, only runoff events that occurred when the ground was frozen, at any measured depth at the weather station, were included in this analysis. Frozen-ground periods typically extended from mid-December through mid-March. Runoff events included those derived from snowmelt only, a combination of rain and snowmelt, and rainfall only. Runoff volume was divided by the basin area and multiplied by a numerical factor to determine runoff depth (mm [in]), which normalized the runoff volume for differences in basin size.

A flow-weighted composite sample was produced for each runoff event at each station by calculating the percentage of the total event volume that each discrete sample represented, collecting appropriate aliquots from each discrete sample using a churn splitter, and combining aliquots. The composite sample was analyzed for concentrations of total dissolved solids, suspended sediment, chloride, nitrate plus nitrite-nitrogen, ammonium nitrogen, total Kjehldahl nitrogen, dissolved reactive $\mathrm{P}$, and total $\mathrm{P}$. The total nitrogen $(\mathrm{TN})$, organic $\mathrm{N}$, and particulate $\mathrm{P}$ fraction of each sample were calculated from the reported results. The resultant constituent concentrations for each flow-weighted sample were multiplied by the event volume and a numerical factor to determine constitu- ent losses $\left(\mathrm{kg} \mathrm{ha}^{-1}\left[\mathrm{lb} \mathrm{ac}{ }^{-1}\right]\right)$ for each event in each basin.

Each monitored basin included portions of two separately managed fields; therefore, manure application rates were adjusted to reflect rates for a basin scale, rather than a field scale (table 2). These adjusted rates, deemed "effective application rates," are field-application rates that account for the percent of each basin that received manure. For example, the effective application rate of a 20 ha $(49.4 \mathrm{ac}$ ) field (within a 40 ha [98.8 ac] basin) that received manure on the entire field would be reported as half that of the actual field application rate.

Manure was surface applied to the fields by the producer at a time, rate, location, and method typical of his operation. Following is a brief synopsis of manure applications and some of the field conditions at the time of application during each study year.Additional details can be found in table 2 .

- Some LDM was applied to basins A and B in September of 2003. Additional LDM was applied on frozen and snowcovered ground in February of 2004, less than one week before the start of snowmelt. Some LDM was applied to basin C in November of 2003, on top of frozen, but not snow-covered, ground.

- Some SBM was applied to all three basins in September and October of 2004. Some LDM was also applied to basin $\mathrm{C}$ in October of 2004. Basin C then received four separate, SBM applications on frozen and snow-covered ground in January and February of 2005. Some applications were made on top of melting snow.

- Some SBM was applied to basins A and $\mathrm{B}$ on frozen and snow-covered ground in early December of 2005 and early January of 2006. Basin C received only SBM in September and October of 2005.

- Some SBM was applied to all three basins in the fall and before the ground froze in mid-December of 2006. Basins A and $\mathrm{B}$ then received three spreader loads of SBM mixed with snow three days before runoff occurred in March of 2007.

Runoff depths and flow-weighted constituent concentrations (and thus constituent losses) were compared using nonparametric tests of data ranks among sets of data for each of the three basins within each year. Differences in depths and concentrations among the monitored basins were considered to be significant at $p<0.05$. Only runoff events that were mutually common among all three basins were used in the statistical analyses. Typically, runoff events were defined from the time when runoff started to the time runoff ended, unless the event contained multiple peaks or lasted several days. In some of these cases, the event was subdivided to provide information regarding runoff volume and constituent-concentration changes throughout the event. Some small runoff events were not sampled, but sample volumes were computed; consequently, the number of values statistically compared for runoff volumes was greater than that for constituent concentrations. Unsampled events typically represented $6 \%$ or less of the total runoff volume measured in any FGP.

\section{Results and Discussion}

Precipitation and Surface Runoff. During winter 2003 to 2004, approximately 744 $\mathrm{mm}$ (29.3 in) of frozen precipitation fell on the basins. Using an averaged ratio of 14 in (355.6 $\mathrm{mm})$ of snowfall to 1 in $(25.4 \mathrm{~mm})$ of liquid-water equivalent determined by Baxter et al. (2005), the liquid-water equivalent (WE) of this frozen precipitation was approximately $53 \mathrm{~mm}$ (2.1 in). An additional $127 \mathrm{~mm}$ (5.0 in) of rain fell on the basins when the ground was frozen. The approximate freeze/thaw dates extended from November 25, 2003, to March 25, 2004. This time frame represents the period in which the ground was persistently frozen at any measured depth. Five runoff events were induced by both snowmelt only and rain on snow during the FGPs between February 18 and 28, 2004 (figure 2a). Runoff depths of 32,28 , and $19 \mathrm{~mm}(1.26,1.10$, and $0.76 \mathrm{in})$ were recorded during this period for basins $\mathrm{A}, \mathrm{B}$, and $\mathrm{C}$, respectively (table 3 ). This frozen period of runoff comprised nearly $60 \%$ of the total runoff volume monitored for the entire year (October 1, 2003, to September $30,2004)$. Approximately $15 \%$ of the total precipitation that fell during the FGP was measured as runoff. Runoff depths were not significantly different among the three basins, even though basins A and B received LDM about five days before the start of runoff (tables 2 and 4).

During the winter of 2004 to 2005 , approximately $925 \mathrm{~mm}$ (36.4 in) of frozen precipitation fell (WE $=66 \mathrm{~mm}[2.6 \mathrm{in}]$ ). Additional rainfall during this FGP totaled 66 $\mathrm{mm}$ (2.6 in). The approximate freeze/thaw dates extended from December 13, 2004, 
Table 2

Manure-application history for each of three monitored basins at a no-till farm in southwest Wisconsin, 2003 to 2007. All manure applications occurred between fall harvest and the end of each period of frozen-ground runoff.

\begin{tabular}{|c|c|c|c|c|c|c|c|c|c|c|}
\hline $\begin{array}{l}\text { Basin } \\
\text { name }\end{array}$ & $\begin{array}{l}\text { Application } \\
\text { date }\end{array}$ & $\begin{array}{l}\text { Field } \\
\text { name }\end{array}$ & $\begin{array}{l}\text { Manure } \\
\text { type }\end{array}$ & \multicolumn{3}{|c|}{ Analysis ( $\mathrm{g} \mathrm{kg}^{-1}$ or $\left.\mathrm{g} \mathrm{L}^{-1}\right)$} & $\begin{array}{l}\text { Dry } \\
\text { matter } \\
\text { (\%) }\end{array}$ & $\begin{array}{l}\text { Application rate } \\
\left(\mathrm{kL} \mathrm{ha}^{-1} \text { or } \mathrm{Mg} \mathrm{ha}^{-1}\right)\end{array}$ & $\begin{array}{l}\text { Area } \\
\text { applied in } \\
\text { basin (\%) }\end{array}$ & $\begin{array}{l}\text { Effective } \\
\text { application rate } \\
\left(\mathrm{KL} \mathrm{ha}^{-1} \text { or } \mathrm{Mg} \mathrm{ha}^{-1}\right)^{*}\end{array}$ \\
\hline \multicolumn{11}{|c|}{ Fall/winter 2003 to 2004} \\
\hline$A$ & $9 / 19 / 2003$ & $160 \mathrm{~A}$ & LDM & 2.3 & 0.3 & 1.5 & 5 & 40.2 & 66 & 26.7 \\
\hline A & $2 / 14 / 2004$ & $160 \mathrm{~A}$ & LDM & 2.3 & 0.3 & 1.5 & 5 & 40.2 & 46 & 18.3 \\
\hline B & $9 / 19 / 2003$ & $160 A$ & LDM & 2.3 & 0.3 & 1.5 & 5 & 40.2 & 77 & 31.1 \\
\hline $\mathrm{C}$ & Nov. 2003 & $160 \mathrm{~B}$ & LDM & 2.3 & 0.3 & 1.5 & 5 & 65.5 & 76 & 50.1 \\
\hline \multicolumn{11}{|c|}{ Fall/winter 2004 to 2005} \\
\hline A & $9 / 18 / 2004$ & $160 C$ & SBM & 10.6 & 3.3 & 7.3 & 25 & 5.4 & 34 & 1.8 \\
\hline A & $10 / 6 / 2004$ & $160 \mathrm{~A}$ & SBM & 10.6 & 3.3 & 7.3 & 25 & 8.3 & 66 & 5.5 \\
\hline C & $10 / 9 / 2004$ & $160 B$ & LDM & 2.2 & 0.4 & 1.7 & 5 & 38.4 & 76 & 29.3 \\
\hline C & $10 / 29 / 2004$ & $160 \mathrm{~B}$ & SBM & 10.6 & 3.3 & 7.3 & 25 & 16.0 & 51 & 8.1 \\
\hline C & $1 / 1 / 2005$ & $160 \mathrm{~B}$ & SBM & 8.7 & 2.9 & 6.1 & 22 & 14.6 & 20 & 3.0 \\
\hline C & $1 / 28 / 2005$ & $160 B$ & SBM & 8.7 & 2.9 & 6.1 & 22 & 14.6 & 15 & 2.2 \\
\hline C & $2 / 12 / 2005$ & $160 \mathrm{~B}$ & SBM & 8.7 & 2.9 & 6.1 & 22 & 7.3 & 51 & 3.7 \\
\hline $\mathrm{C}$ & $2 / 19 / 2005$ & $160 B$ & SBM & 8.7 & 2.9 & 6.1 & 22 & 11.2 & 39 & 4.4 \\
\hline \multicolumn{11}{|c|}{ Fall/winter 2005 to 2006} \\
\hline A & $12 / 1 / 2005$ & $160 \mathrm{~A}$ & SBM & 8.7 & 2.9 & 6.1 & 22 & 5.6 & 33 & 1.9 \\
\hline A & $1 / 1 / 2006$ & $160 \mathrm{~A}$ & SBM & 8.7 & 2.9 & 6.1 & 22 & 5.6 & 33 & 1.9 \\
\hline A & $12 / 20 / 2006$ & $160 \mathrm{C}$ & SBM & 8.8 & 3.4 & 5.4 & 30 & 8.3 & 34 & 2.8 \\
\hline A & $3 / 6 / 2007$ & $160 \mathrm{~A}$ & SBM & - & - & - & - & 29.1 & 4 & 1.3 \\
\hline B & $10 / 11 / 2006$ & $160 \mathrm{~A}$ & SBM & 8.8 & 3.4 & 5.4 & 30 & 8.3 & 39 & 3.2 \\
\hline B & $10 / 28 / 2006$ & $160 \mathrm{~A}$ & SBM & 8.8 & 3.4 & 5.4 & 30 & 8.3 & 39 & 3.2 \\
\hline B & $12 / 20 / 2006$ & $160 C$ & SBM & 8.8 & 3.4 & 5.4 & 30 & 8.3 & 22 & 1.8 \\
\hline B & $3 / 6 / 2007$ & $160 \mathrm{~A}$ & SBM & - & - & - & - & 29.1 & 13 & 3.8 \\
\hline C & $10 / 28 / 2006$ & $160 B$ & SBM & 8.8 & 3.4 & 5.4 & 30 & 9.6 & 76 & 7.4 \\
\hline C & $12 / 27 / 2006$ & $160 C$ & SBM & 8.8 & 3.4 & 5.4 & 30 & 16.6 & 22 & 3.7 \\
\hline
\end{tabular}

Notes: $\mathrm{N}=$ nitrogen. $\mathrm{P}=$ phosphorus. $\mathrm{K}=$ potassium. $\mathrm{LDM}=$ liquid-dairy manure. $\mathrm{SBM}=$ solid-beef manure with bedding corn stalks. $-=$ manure analysis and percent dry matter not determined.

* Effective application rate is the application rate multiplied by the percentage of area applied within the basin.

to April 3, 2005. Twenty-two runoff events were recorded, totaling 111,96 , and $70 \mathrm{~mm}$ $(4.38,3.79$, and 2.75 in) for basins $\mathrm{A}, \mathrm{B}$, and $\mathrm{C}$, respectively. A majority of runoff occurred during rain on snow events on February 5 to 7 and February 13 to 15,2005 (figure 2b). Approximately $70 \%$ of total precipitation that fell during the FGP was measured as runoff and comprised nearly 100\% of the total monitored runoff for the entire year. This percentage was much greater than during the 2003 to 2004 FGP, possibly because a 


\section{Figure 2}

Mean daily runoff, cumulative daily rainfall, and mean daily air temperatures from January 1 to March 31 for each of the monitored winter periods: (a) 2004, (b) 2005, (c) 2006, and (d) 2007. Date for frozen-ground periods preceding January 1 are not shown because no runoff occurred at any station. Fields were not necessarily frozen for the entire period shown for each year.

(a)

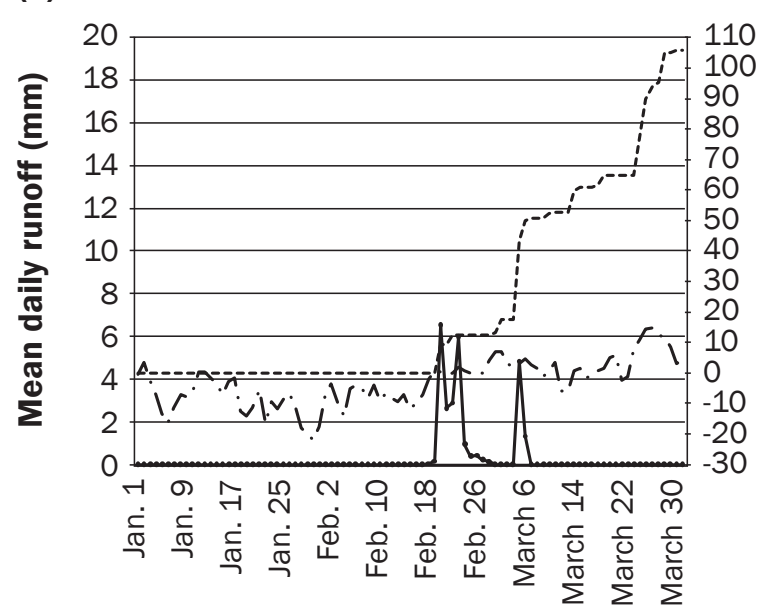

(c)

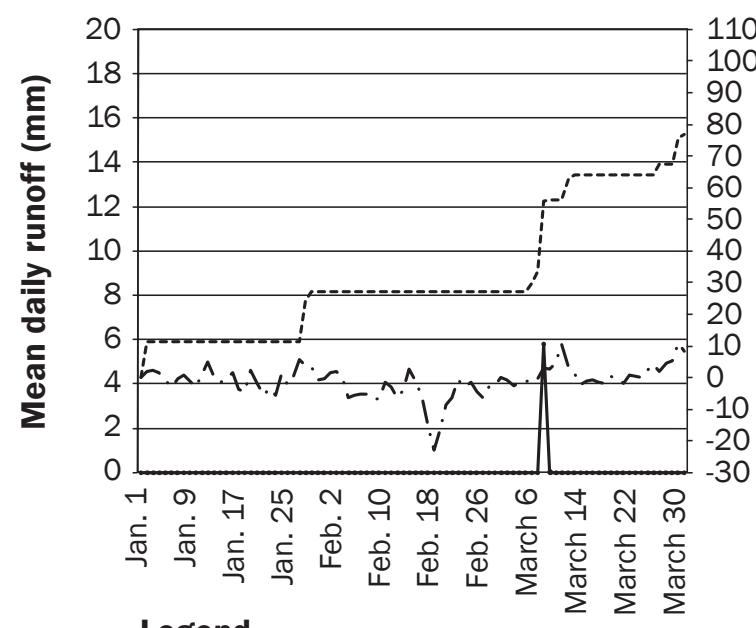

Legend (b)
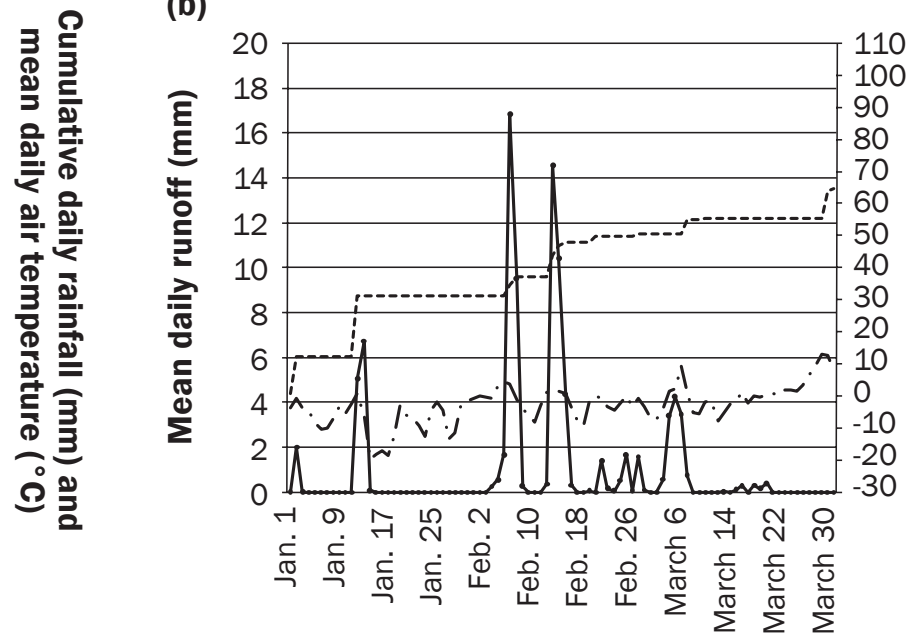

(d)
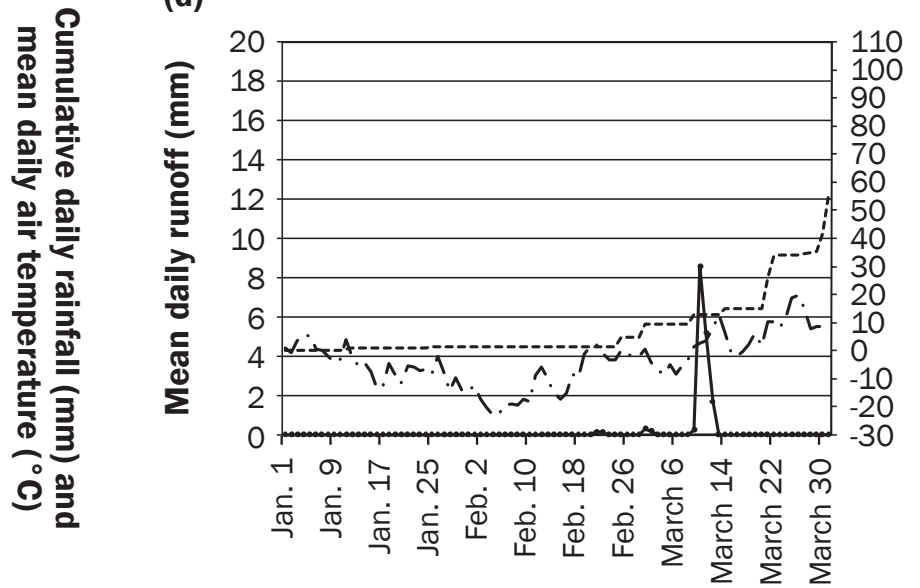

-... Rainfall

—. Air temperature

particularly widespread ice layer had formed on the soil surface and limited infiltration. Runoff depths did not differ significantly among the three basins, even though basin $\mathrm{C}$ received multiple applications of SBM throughout the FGP, some on melting snow.

During the winter of 2005 to 2006, approximately $945 \mathrm{~mm}$ (37.2 in) of frozen precipitation fell (WE $=68 \mathrm{~mm}[2.7 \mathrm{in}]$ ). Rainfall during this FGP totaled $64 \mathrm{~mm}$ (2.5 in), and the approximate freeze/thaw dates extended from December 2, 2005, to March 26, 2006. Although precipitation amounts were similar to those in previous years, only one FGP runoff event occurred during a rain on snow event on March 8 to 9, 2006 (figure 2c). This event was the only runoff recorded for the entire year. An early snow pack formed in November and December, limiting soil frost development and possibly allowing increased infiltration. Approximately $5 \%$ of total precipitation that fell during the FGP was measured as runoff. No statistics were computed on the data for this FGP.

During the winter of 2006 to 2007 , approximately $1,168 \mathrm{~mm}$ (46.0 in) of frozen precipitation fell (WE $=84 \mathrm{~mm}[3.3 \mathrm{in}])$.
Rainfall during this FGP totaled $58 \mathrm{~mm}(2.3$ in), and the approximate freeze/thaw dates extended from December 1, 2006, to March 24, 2007. Six runoff events were recorded, totaling 7,15 , and $27 \mathrm{~mm}(0.28,0.60$, and 1.06 in) for basins $\mathrm{A}, \mathrm{B}$, and $\mathrm{C}$, respectively. A majority of runoff occurred on March 10 to 12,2007 , (figure 2d) which was almost exclusively from melting snow due to warm air temperatures. This runoff comprised about $80 \%$ of the total monitored runoff for the entire year. Approximately $12 \%$ of total precipitation that fell during the FGP was 


\section{Table 3}

Total runoff depth and mean flow-weighted concentrations of sediment, total nitrogen (TN), and total phosphorus (TP) in runoff during frozen-ground periods (FGP) for winters from 2003 to 2004 through 2006 to 2007.

\begin{tabular}{|c|c|c|c|c|c|}
\hline $\begin{array}{l}\text { Basin } \\
\text { name }\end{array}$ & Residue type* & $\begin{array}{l}\begin{array}{l}\text { Runoff } \\
(\mathrm{mm})\end{array} \\
\end{array}$ & $\begin{array}{l}\text { Sediment } \\
\left(\mathrm{mg} \mathrm{L}^{-1}\right)\end{array}$ & $\begin{array}{l}\mathrm{TN} \\
\left(\mathrm{mg} \mathrm{L}^{-1}\right)\end{array}$ & $\begin{array}{l}\text { TP } \\
\left(\mathrm{mg} \mathrm{L}^{-1}\right)\end{array}$ \\
\hline \multicolumn{6}{|c|}{ FGP winter 2003 to 2004 ( $n=6$ [runoff], $n=5$ [constituents]) } \\
\hline A & Corn/corn & $32.0 a$ & $38.7 a$ & $31.8 \mathrm{c}$ & $10.9 c$ \\
\hline B & Corn/corn & $27.9 a$ & $80.7 b$ & $21.2 b$ & $8.4 b$ \\
\hline C & Corn/soybean-corn $\dagger$ & $19.3 a$ & $17.0 \mathrm{a}$ & $3.8 \mathrm{a}$ & $2.3 a$ \\
\hline \multicolumn{6}{|c|}{ FGP winter 2004 to 2005 ( $n=22$ [runoff], $n=9$ [constituents]) } \\
\hline A & Corn/soybean & $111.2 a$ & $14.1 \mathrm{a}$ & $3.1 \mathrm{a}$ & $1.8 a$ \\
\hline B & Corn/soybean & $96.2 \mathrm{a}$ & $17.9 a$ & $3.1 a$ & $1.9 a$ \\
\hline C & Soybean-corn $\uparrow /$ corn-soybean $\dagger$ & $69.8 \mathrm{a}$ & $45.1 \mathrm{a}$ & $11.5 b$ & $5.8 \mathrm{~b}$ \\
\hline \multicolumn{6}{|c|}{ FGP winter 2005 to $2006 \ddagger$} \\
\hline $\mathrm{A}$ & Soybean/corn & 13.70 & 61.0 & 8.0 & 7.7 \\
\hline B & Soybean/corn & $<0.01$ & $<0.01$ & $<0.01$ & $<0.01$ \\
\hline$\underline{\mathrm{C}}$ & Corn-soybeant/corn & 3.70 & 205.0 & 11.0 & 5.6 \\
\hline \multicolumn{6}{|c|}{ FGP winter 2006 to 2007 ( $n=6$ [runoff], $n=3$ [constituents]) } \\
\hline A & Corn/corn & $7.1 \mathrm{a}$ & $24.7 a$ & $4.0 \mathrm{a}$ & $3.1 \mathrm{a}$ \\
\hline $\mathrm{B}$ & Corn/corn & $17.0 \mathrm{a}$ & $32.4 a$ & $7.8 \mathrm{a}$ & $6.7 a$ \\
\hline $\mathrm{C}$ & Corn/soybean-corn $†$ & $27.0 \mathrm{a}$ & $248.1 b$ & $5.7 a$ & $3.6 a$ \\
\hline
\end{tabular}

Notes: Values within a column and year followed by the same letter are not significantly different at $p<0.050$; letters correspond to nonparametric analysis based on data ranks rather than means as shown.

* Both the residue and the upcoming crop are listed. For example, corn/corn shows that the basin had corn removed in the previous fall (thus the residue) and is going back into corn the next spring.

† This basin contains two fields. The first residue type listed comprises $80 \%$ of the basin area, while the second listed comprises $20 \%$.

‡ Statistics not computed.

measured as runoff. Surface runoff depths did not differ statistically among the three basins.

Runoff depths compared among each of the three basins were not different in any given year, despite each basin receiving different types of manure at varying rates and times. Other studies have shown decreased runoff due to manure applications (Ginting et al. 1998; Young and Holt 1977; Kongoli and Bland 2002). It is possible that the relatively low application rates used in this study were not great enough to affect runoff volumes.

Despite relatively similar precipitation amounts during each FGP, both the number and volume of runoff events varied greatly from year-to-year. From site observations, it appeared that runoff amounts were more related to the timing and type (snow/ sleet/rain) of precipitation, intensity of precipitation (rainfall), air temperatures, and snow-pack properties such as depth, water equivalent, ice layers, and temperature, rather than soil temperatures or frost depth alone.

Sediment. Mean flow-weighted concentrations of suspended sediment in runoff during FGPs were low, ranging between 7 and $248 \mathrm{mg} \mathrm{L}^{-1}$ (table 3). Sediment losses during FGPs were also low, with each site typically having less than $22 \mathrm{~kg} \mathrm{ha}^{-1}(20 \mathrm{lb}$ $\mathrm{ac}^{-1}$ ) measured during any FGP (table 4). Sediment concentrations in basin B were significantly greater than in the other two basins during the 2003 to 2004 FGP, while concentrations in basin $\mathrm{C}$ were significantly greater than in the other two basins during the 2006 to 2007 FGP.

These differences were not associated with the presence or absence of LDM or SBM, nor were they influenced by the amount of runoff. Rather, basin-specific conditions were likely contributing factors. Greater concentrations in basin B during the 2003 to 2004 FGP were likely the result of terrace maintenance, and, to a lesser degree, to the reshaping of the waterway during the installation of the monitoring site in the fall of 2003. The greater concentrations in basin C during the 2006 to 2007 FGP were likely the result of soil erosion from end rows due to disturbance by farm equipment during harvest, which was observed at a location near the monitoring station. Regardless, the relatively low suspended sediment concentrations and losses observed are consistent with Hansen et al. (2000), who showed that wintertime runoff is not expected to cause significant soil erosion because of the slower rate of snowmelt compared to rainfallinduced runoff. Soil particles may also be less likely to become entrained in runoff when frozen together.

Nitrogen. During the FGP of winter 2003 to 2004 , mean flow-weighted concentrations and losses of TN in runoff from basin A were significantly greater than in basin $\mathrm{B}$, and TN in both basins $\mathrm{A}$ and $\mathrm{B}$ was greater than in basin C (table 3, 4). Individual event-mean concentrations of TN ranged from 9.3 to $69.7 \mathrm{mg} \mathrm{L}^{-1}$ in basins A and B and from 2.8 to $5.1 \mathrm{mg} \mathrm{L}^{-1}$ in basin C. Total nitrogen losses ranged from 0.7 to $10.1 \mathrm{~kg} \mathrm{ha}^{-1}$ (0.6 to 9.0 $\mathrm{lb} \mathrm{ac} \mathrm{ac}^{-1}$ ) among basins for the same period. These FGP losses comprised about $80 \%$, $60 \%$, and $40 \%$ of annual TN losses in basins A, B, C, respectively.

The greatest TN concentrations for the 2003 to 2004 FGP were observed during the onset of runoff in basins A and B and generally decreased over time. Total nitrogen concentrations were relatively constant throughout the runoff period in basin C. Although the amount of nitrogen applied in manure was relatively similar among the basins (table 4), basins A and B (which received LDM on top of snow, less than one week preceding snowmelt) exhibited significantly greater TN concentrations and losses. The greater concentrations observed in basin A compared to B are likely due to the greater effective application rate during the February 14, 2004, LDM application. These observations suggest that both the timing and amount of applied LDM were important factors for concentrations and losses of $\mathrm{TN}$ in runoff during FGPs.

Assuming that only nitrogen $(\mathrm{N})$ from manure contributed to TN in runoff, TN losses from basins $\mathrm{A}, \mathrm{B}$, and $\mathrm{C}$ comprised $10 \%, 6 \%$, and $1 \%$ of the TN that was applied after crop harvest (table 4). If only the TN added during the February LDM application to basins A and B was a significant TN component in runoff, $24 \%$ and $29 \%$ of this TN applied was measured in runoff, respectively. These percentages should be considered to be conservatively high since it was assumed 
Table 4

Suspended sediment, total nitrogen (TN), and total phosphorus (TP) losses in runoff; nutrients applied in manure and the percentage of those nutrients measured in runoff; and days between manure application and runoff during frozen-ground periods (FGP) for winters from 2003 to 2004 through 2006 to 2007. Calculated percentages assume that only nutrients applied in manure contributed to runoff.

\begin{tabular}{|c|c|c|c|c|c|c|c|c|c|c|c|c|c|c|}
\hline \multirow{2}{*}{$\begin{array}{l}\text { Basin } \\
\text { name }\end{array}$} & \multirow{2}{*}{\multicolumn{3}{|c|}{ Runoff losses (kg ha-1) }} & \multicolumn{5}{|c|}{ Total nutrients applied in manure (kg ha $\left.{ }^{-1}\right)$} & \multicolumn{5}{|c|}{$\begin{array}{l}\text { Nutrients in } \\
\text { manure applied on snow only }\left(\mathrm{kg} \mathrm{ha}^{-1}\right)\end{array}$} & \multirow{2}{*}{$\begin{array}{l}\text { Days between } \\
\text { last manure } \\
\text { application and } \\
\text { first runoff event }\end{array}$} \\
\hline & & & & $\begin{array}{l}\text { Manure } \\
\text { type }\end{array}$ & $\mathbf{N}$ & $\begin{array}{l}\text { Applied } \\
\mathrm{N} \text { in } \\
\text { runoff } \\
(\%)\end{array}$ & $\mathbf{P}$ & $\begin{array}{l}\text { Applied } \\
P \text { in } \\
\text { runoff } \\
(\%)\end{array}$ & $\begin{array}{l}\text { Manure } \\
\text { type }\end{array}$ & $\mathbf{N}$ & $\begin{array}{l}\text { Applied } \\
\mathrm{N} \text { in } \\
\text { runoff } \\
(\%)\end{array}$ & $\mathbf{P}$ & $\begin{array}{l}\text { Applied } \\
\text { P in } \\
\text { runoff } \\
(\%)\end{array}$ & \\
\hline \multicolumn{15}{|c|}{ FGP winter 2003 to 2004} \\
\hline A & 12.3 & 10.1 & 3.5 & LDM* & 103 & 10 & 15 & 24 & LDM* & 42 & 24 & 6 & 62 & 4 \\
\hline $\mathrm{C}$ & 3.3 & 0.7 & 0.4 & $\mathrm{LDM}^{*}$ & 114 & 1 & 17 & 2 & na & na & na & na & na & 88 \\
\hline \multicolumn{15}{|c|}{ FGP winter 2004 to 2005} \\
\hline A & 15.7 & 3.4 & 2.0 & $\mathrm{SBM}+$ & 77 & 4 & 24 & 9 & na & na & na & na & na & 88 \\
\hline B & 17.2 & 3.0 & 1.8 & $\mathrm{SBM}+$ & 81 & 4 & 25 & 7 & na & na & na & na & na & 87 \\
\hline $\mathrm{C}$ & 31.5 & 8.0 & 4.0 & Both & 279 & 3 & 80 & 5 & SBM† & 116 & 7 & 38 & 11 & 0 \\
\hline C & 7.5 & 0.4 & 0.2 & $\mathrm{SBM}+$ & 135 & $<1$ & 45 & $<1$ & na & na & na & na & na & 159 \\
\hline \multicolumn{15}{|c|}{ FGP winter 2006 to 2007} \\
\hline A & 1.8 & 0.3 & 0.2 & SBM & 73 & $<1$ & 28 & $<1$ & SBM & $\ddagger$ & $\ddagger$ & $\ddagger$ & $\ddagger$ & 3 \\
\hline B & 5.0 & 1.3 & 1.1 & SBM & 72 & 2 & 28 & 4 & SBM & $\ddagger$ & $\ddagger$ & $\ddagger$ & $\ddagger$ & 4 \\
\hline C & 67.0 & 1.5 & 1.0 & SBM† & 96 & 2 & 38 & 3 & na & na & na & na & na & 56 \\
\hline
\end{tabular}

Notes: na $=$ not applicable. $\mathrm{N}=$ nitrogen. $\mathrm{P}=$ phosphorus.

* Liquid-dairy manure (LDM), average analysis $2.3 \mathrm{~g} \mathrm{~L}^{-1}$ nitrogen, $0.8 \mathrm{~g}$ phosphorus oxide $\mathrm{L}^{-1}, 1.9 \mathrm{~g}$ potassium oxide $\mathrm{L}^{-1}$, and $5 \%$ dry matter.

† Solid-beef manure (SBM) with bedding corn stalks, average analysis $9.3 \mathrm{~g} \mathrm{~N} \mathrm{~kg}^{-1}, 7.2 \mathrm{~g}$ phosphorus oxide $\mathrm{kg}^{-1}, 7.4 \mathrm{~g}$ potassium oxide kg-1, and $30 \%$ dry matter.

$\ddagger$ The amount of total nutrients applied on snow is unknown but is assumed to be relatively small.

that no $\mathrm{N}$ sources other than manure were significant contributors.

During the FGP of winter 2004 to 2005, concentrations and losses of TN in runoff from basin $\mathrm{C}$ were significantly greater than those in basins A and B. Individual eventmean concentrations of TN ranged from 3.3 to $23.8 \mathrm{mg} \mathrm{L}^{-1}$ in basin $\mathrm{C}$ and from 1.7 and $7.4 \mathrm{mg} \mathrm{L}^{-1}$ in basins $\mathrm{A}$ and $\mathrm{B}$. The greatest TN concentrations in basin $\mathrm{C}$ occurred during runoff periods in which SBM was recently applied on top of melting snow. This suggests that the timing of applied SBM was also an important factor for TN losses in runoff. The TN losses recorded during this FGP ranged from 3.0 to $8.0 \mathrm{~kg} \mathrm{ha}^{-1}(2.7$ and $7.1 \mathrm{lb} \mathrm{ac}^{-1}$ ) and comprised nearly $100 \%$ of the TN measured for the entire year in each basin. Assuming that only $\mathrm{N}$ from manure contributed to TN in runoff, TN losses from basins $\mathrm{A}, \mathrm{B}$, and $\mathrm{C}$ comprised $4 \%, 4 \%$, and $3 \%$ of the TN that was applied in manure after crop harvest, respectively. If only the $\mathrm{N}$ added to basin $\mathrm{C}$ during the January and
February SBM applications was a significant TN component in runoff, $7 \%$ of this TN applied was measured in runoff. This percentage was lower than the one for the LDM applied shortly preceding snowmelt to basins $A$ and B during the FGP of winter 2003 to 2004, even though approximately four times more TN was applied and runoff was over twice as great. While the application of LDM or SBM to frozen and snow-covered ground shortly preceding snowmelt increased TN concentrations and losses in runoff, these observations suggest that contributions to runoff from the application LDM may be greater than those for SBM applied at similar rates, times, and field conditions.

Despite the fact that SBM was applied to basins A and B shortly preceding runoff during the 2006 to 2007 winter, TN concentrations and losses were not significantly different among basins. This is possibly due to the fact that only a small amount of $\mathrm{TN}$ in SBM (actual amount applied was unknown, but observations indicated that the applica- tion was a mixture of manure and snow) was applied to basins $A$ and $B$, which suggests that the rate of SBM applied can also impact TN concentrations and losses. Individual eventmean concentrations in runoff ranged from 3.0 to $8.9 \mathrm{mg} \mathrm{L}^{-1}$ among the basins, with measured TN losses comprising less than $2 \%$ of that applied in manure. Total nitrogen losses during this FGP comprised about $50 \%$, $100 \%$, and $70 \%$ of annual TN losses in basins A, B, C, respectively.

The forms of $\mathrm{N}$ can be used to help evaluate the potential impacts of manure applications to the environment that are not necessarily described by TN alone. Nitrogen inputs-particularly nitrate-nitrogen-to water bodies limited by $\mathrm{N}$ are a well-documented concern (Cerco 1995; Rabalais et al. 2001, 2002). Another concern is $\mathrm{N}$ toxicity to fish and other aquatic organisms. Toxic forms of $\mathrm{N}$ to aquatic species include unionized ammonia and the ammonium ion (USEPA 1999). Ammonia is generally considered to be more toxic, with 
the degree of toxicity primarily dependent upon $\mathrm{pH}$ and temperature. Ammonium nitrogen (ammonium $\mathrm{N}$ ) reported in this article is the total concentration reported for the sum of both unionized ammonia and ammonium ion. Actual amounts of unionized ammonia were not calculated because $\mathrm{pH}$ and temperature were not measured.

The highest mean flow-weighted concentrations of ammonium $\mathrm{N}$ occurred during the FGP of winter 2003 to 2004 (table 5). Individual event-mean concentrations of ammonium $\mathrm{N}$ during this period ranged from 1.6 to $43.6 \mathrm{mg} \mathrm{L}^{-1}$ at basin A and from 1.2 to $18.6 \mathrm{mg} \mathrm{L}^{-1}$ at basin B. Each basin received LDM on frozen and snow-covered ground shortly preceding runoff. In basin A, event-mean concentrations exceeded 20 $m g \mathrm{~L}^{-1}$ for several events on consecutive days when manure was observed in the runoff water. The highest ammonium $\mathrm{N}$ concentrations during these events were often associated with high organic-N concentrations but relatively low nitrate plus nitrite $\mathrm{N}$ concentrations. Ammonium N concentrations in runoff ranged between 0.1 and 1.4 $\mathrm{mg} \mathrm{L}^{-1}$ at basin C, which received only LDM in November 2003 on top of frozen-but not snow-covered-ground. At the onset of runoff in this basin, the LDM had been applied to the basin for nearly three months.

During the FGP of winter 2004 to 2005, mean flow-weighted concentrations of ammonium $\mathrm{N}$ in basin $\mathrm{C}$ were not as high as those from basins $\mathrm{A}$ and $\mathrm{B}$ during the previous winter. Individual event-mean ammonium $\mathrm{N}$ concentrations were also lower in basin $\mathrm{C}$, ranging from 0.4 to 9.5 $\mathrm{mg} \mathrm{L}^{-1}$. These lower concentrations occurred despite the fact that basin $\mathrm{C}$ received SBM on top of frozen and snow-covered ground shortly preceding runoff and that approximately four times more $\mathrm{N}$ was applied in the SBM application than the LDM application the previous year. The lower ammonium $\mathrm{N}$ concentrations could have been the result of dilution by greater runoff volumes, different runoff conditions, and/or by inherently lower ammonium $\mathrm{N}$ concentrations in the SBM compared to the LDM.

Phosphorus. The total phosphorus (TP) concentrations and losses in runoff during FGPs and the relations between these losses and manure applications were similar to those for TN. During the FGP of winter 2003 to 2004, mean flow-weighted concentrations and losses of TP in runoff from basin A were

Table 5

Mean flow-weighted concentrations of nitrogen and phosphorus species in runoff during frozen-ground periods (FGP) for winters from 2003 to 2004 through 2006 to 2007.

\begin{tabular}{|c|c|c|c|c|c|}
\hline \multirow[b]{3}{*}{$\begin{array}{l}\text { Basin } \\
\text { name }\end{array}$} & \multirow{2}{*}{\multicolumn{3}{|c|}{ Nitrogen }} & \multicolumn{2}{|l|}{ Phosphorus } \\
\hline & & & & \multirow{2}{*}{$\begin{array}{l}\text { Dissolved } \\
\text { reactive } P \\
\left(\mathrm{mg} \mathrm{L}^{-1}\right)\end{array}$} & \multirow[b]{2}{*}{$\begin{array}{l}\text { Particulate P } \\
\left(\mathrm{mg} \mathrm{L}^{-1}\right)\end{array}$} \\
\hline & $\begin{array}{l}\text { Nitrate plus } \\
\text { nitrite } \mathbf{N}\left(\mathrm{mg} \mathrm{L}^{-1}\right)\end{array}$ & $\begin{array}{l}\text { Ammonium N } \\
\left(\mathrm{mg} \mathrm{L}^{-1}\right)\end{array}$ & $\begin{array}{l}\text { Organic N } \\
\left(\mathrm{mg} \mathrm{L}^{-1}\right)\end{array}$ & & \\
\hline \multicolumn{6}{|c|}{ FGP winter 2003 to 2004} \\
\hline $\bar{A}$ & 2.0 & 12.2 & 17.5 & 8.2 & 2.7 \\
\hline $\mathrm{B}$ & 0.8 & 9.9 & 10.5 & 6.7 & 1.8 \\
\hline $\mathrm{C}$ & 1.6 & 0.4 & 1.9 & 2.0 & 0.3 \\
\hline \multicolumn{6}{|c|}{ FGP winter 2004 to 2005} \\
\hline A & 0.9 & 0.7 & 1.5 & 1.8 & 0.0 \\
\hline B & 1.0 & 0.8 & 1.3 & 1.9 & 0.0 \\
\hline$\underline{\mathrm{C}}$ & 0.6 & 1.9 & 9.0 & 5.2 & 0.5 \\
\hline \multicolumn{6}{|c|}{ FGP winter 2005 to 2006} \\
\hline $\bar{A}$ & 2.1 & 1.7 & 4.2 & 6.6 & 1.1 \\
\hline $\mathrm{B}$ & $<0.01$ & $<0.01$ & $<0.01$ & $<0.01$ & $<0.01$ \\
\hline $\mathrm{C}$ & 1.3 & 0.8 & 8.9 & 3.2 & 2.4 \\
\hline \multicolumn{6}{|c|}{ FGP winter 2006 to 2007} \\
\hline $\mathrm{A}$ & 0.6 & 1.0 & 2.5 & 1.5 & 1.6 \\
\hline $\mathrm{B}$ & 0.3 & 3.2 & 4.3 & 6.5 & 0.2 \\
\hline C & 0.9 & 1.9 & 2.9 & 3.1 & 0.5 \\
\hline
\end{tabular}

significantly greater than in basin $\mathrm{B}$, and TP in both basins $\mathrm{A}$ and $\mathrm{B}$ was greater than in basin C (tables 3 and 4). Individual eventmean TP concentrations ranged from 2.7 to $28.3 \mathrm{mg} \mathrm{L}^{-1}$ in basins A and B and from 1.6 to $3.2 \mathrm{mg} \mathrm{L}^{-1}$ in basin $\mathrm{C}$. As was the case for $\mathrm{TN}$, the timing of the LDM application was likely an important factor for greater concentrations and losses of TP in runoff during FGPs. Also, the greater effective application rate of LDM in basin A on February 14, 2004, likely increased TP concentrations and losses compared to those in basin B.

Assuming that only $\mathrm{P}$ from manure contributed to TP in runoff, TP losses from basins A, B, and C measured 24\%, 18\%, and $2 \%$ of the $\mathrm{P}$ that was applied in manure after crop harvest. If only the $\mathrm{P}$ added during the February LDM application to basins $\mathrm{A}$ and $\mathrm{B}$ was a significant TP component in runoff during the FGP of the winter of 2003 to $2004,62 \%$ and $70 \%$ of TP applied was measured in runoff, respectively. These percentages should be considered to be conservatively high since it was assumed that no $\mathrm{P}$ sources other than manure were significant contributors. Total phosphorus measured in runoff during this FGP comprised about $80 \%, 66 \%$, and $54 \%$ of the annual TP losses in basins A, B, and C, respectively.

During the FGP of the winter of 2004 to 2005, concentrations and losses of TP in basin $\mathrm{C}$ were significantly greater than in basins A and B. Individual event-mean TP concentrations ranged from 1.0 to 4.8 $\mathrm{mg} \mathrm{L^{-1 }}$ in basins $\mathrm{A}$ and $\mathrm{B}$ and from 2.3 to $11.2 \mathrm{mg} \mathrm{L}^{-1}$ in basin C. The timing of SBM application in relation to runoff was likely an important factor for these greater concentrations and losses. As with TN, the losses during this FGP comprised nearly $100 \%$ of the TP losses measured for the entire year. Assuming that only $\mathrm{P}$ from manure contributed to $\mathrm{P}$ in runoff, TP losses from basins $\mathrm{A}$, $\mathrm{B}$, and $\mathrm{C}$ measured $9 \%, 7 \%$, and $5 \%$ of the TP that was applied in manure after crop harvest, respectively. If only the $\mathrm{TP}$ added during the January and February SBM applications to basin $\mathrm{C}$ was a significant TP component in runoff during this FGP, 11\% was measured in runoff.This percentage was lower than for the LDM applied shortly preceding snowmelt to basins A and B during the FGP of winter 2003 to 2004, even though approximately eight times more TP was applied and runoff was over twice as great. Similar to the findings for $\mathrm{TN}$, these observations suggest that the TP contributions to runoff from the application of LDM may be greater than those for SBM applied at similar rates, times, and field conditions.

Total phosphorus concentrations and losses were not significantly different among basins for the monitored runoff events dur- 
ing the FGP of winter 2006 to 2007, which is most likely a result of only a relatively small amount of TP being applied in basins A and $\mathrm{B}$ shortly preceding runoff. This result suggests that SBM applications made prior to the FGP can result in lower TP concentrations and losses in runoff compared to applications made to frozen and snow-covered ground shortly preceding runoff. Concentrations in runoff ranged from 0.6 to $7.3 \mathrm{mg} \mathrm{L}^{-1}$ among the basins, with measured TP losses in runoff being $4 \%$ or less of that applied in manure. The TP losses during this FGP comprised $76 \%, 100 \%$, and $78 \%$ of the annual TP losses in basins A, B, and C, respectively.

Differentiating between $\mathrm{P}$ forms in runoff can help managers to determine the potential impacts on aquatic resources and the best ways to mitigate these impacts. Approximately $75 \%$ of all TP measured in runoff during the FGP of the winter of 2003 to 2004 was dissolved reactive phosphorus, and greater than $90 \%$ of dissolved reactive phosphorus was measured for the FGP of winter 2004 to 2005 (table 5). On average, dissolved reactive phosphorus accounted for over $80 \%$ of all $\mathrm{P}$ measured in runoff during FGPs throughout the study period.Variations in $\mathrm{P}$ (and dissolved reactive phosphorus) concentrations and losses measured in runoff were likely related to the timing, rate, and form of manure applications, characteristics of runoff, and field condition at the time of runoff-not just soil-test $\mathrm{P}$ values alone. These results are supported by other studies that have shown soil-test $\mathrm{P}$ to be a good indicator of the potential for dissolved $\mathrm{P}$ to be lost in runoff, except when manures are applied (Vadas et al. 2005a, 2005b; McDowell and Sharpley 2002). In this study, soil-test P values were relatively similar among the three basins, yet dissolved reactive phosphorus in runoff was wide-ranging.

\section{Summary and Conclusions}

Nutrients and sediment in surface runoff from frozen agricultural fields were monitored within three small (16.0 ha [39.5 ac] or less), adjacent basins at a no-till farm in southwest Wisconsin during four winters from 2003 to 2004 through 2006 to 2007. Runoff depths and flow-weighted constituent concentrations were compared to determine the impacts of surface-applied LDM or SBM to frozen and/or snow-covered ground.

Average runoff volumes were highly variable among years, but runoff depths were not significantly different among basins within each FGP. Neither the type of manure nor the rates of application significantly affected runoff volumes. Runoff was more likely related to the form, timing, and intensity of precipitation (rainfall), air and soil temperatures, and snow-pack properties, such as depth, water equivalent, and temperature. Runoff during FGPs comprised from 60\% to $100 \%$ of the total runoff measured within any given year. Most FGP runoff occurred in February and/or March.

Sediment concentrations and losses in runoff during the FGPs were low (generally less than $22 \mathrm{~kg} \mathrm{ha}^{-1}\left[20 \mathrm{lb} \mathrm{ac}^{-1}\right]$ in any year). Any nutrients associated with sediment particles were therefore also low. Although statistical comparisons showed that suspended sediment concentrations and losses occasionally differed among basins within a given year, these differences were not related to the presence or absence of LDM or SBM, nor were they influenced by the amount of runoff. Rather, localized in-field conditions were likely contributing factors.

Concentrations and losses of nitrogen and phosphorus were significantly greater in basins that had either LDM or SBM applied to frozen and snow-covered ground less than one week preceding runoff. These increases occurred despite relatively low manure-application rates. Lower concentrations and losses were measured in basins that had manure applied in fall and early winter and an extended period of time (months) had elapsed before runoff. Nutrient losses measured in runoff during the FGPs were substantial, accounting for $40 \%$ to $100 \%$ of the annual total nitrogen and TP losses in any given year. Greater than $80 \%$ of all $\mathrm{P}$ measured in runoff during FGPs was dissolved.

The application of manure to cropped fields during FGPs is part of the management strategy for many livestock producers in continental-climate regions. The results of this study indicate that both LDM and SBM applied to frozen and snow-covered fields less than one week preceding runoff can significantly contribute to nitrogen and phosphorus losses in runoff. Future research targeted at defining the relationships between the timing of manure applications and the amount of nutrients in runoff would allow for determining suitable application periods or field conditions that would potentially minimize nutrient contributions to runoff from agricultural fields. Additional research examining the differences between applications rates and methods, cropping types and/ or tillage types, and more detailed analysis of the impacts of different manure types would enable manure-management guidance among different producer types and management styles.

\section{Acknowledgements}

The authors would like to thank the farm family for access and for generous offerings of their time and equipment. Discovery Farms staff-Kevan Klingberg, Susan Frame, and Tim Popple-were instrumental in providing on-farm information. Funding was also provided by the Wisconsin Milk Marketing Board, Wisconsin Dairy Business Association, Wisconsin Farm Bureau, Professional Dairy Producers of Wisconsin, Wisconsin Pork Producers Association, and the Natural Resources Conservation Service. Further thanks are extended to Dave Owens (US Geological Survey) for technical assistance.

\section{References}

Andraski, B.J., T.C. Daniel, B. Lowery, and D.H. Mueller. 1985. Runoff results from natural and simulated rainfall for four tillage systems. Transactions of the American Society of Agricultural Engineers 28:1219-1225.

Baxter, M.A., C.E. Graves, and J.T. Moore. 2005. A climatology of snow-to-liquid ratio for the contiguous United States. Weather and Forecasting 20:729-744

Cerco, C.F. 1995. Response of Chesapeake Bay to nutrient load reductions. Journal of Environmental Engineering 121:549-557.

Cox, F.R., and S.E. Hendricks. 2000. Soil test phosphorus and clay content effects on runoff water quality. Journal of Environmental Quality 29:1582-1586.

Ginting, D., J.F. Moncrief, S.C. Gupta, and S.D. Evans. 1998. Corn yield, runoff, and sediment losses from manure and tillage systems. Journal of Environmental Quality 27:1396-1402.

Hansen, N.C., S.C. Gupta, and J.F. Moncrief. 2000. Snowmelt runoff, sediment, and phosphorus losses under three different tillage systems. Soil \& Tillage Research 57:93-100.

Klausner, S.D., P.J. Zwerman, and D.F. Ellis. 1976. Nitrogen and phosphorus losses from winter disposal of dairy manure. Journal of Environmental Quality 5:47-49.

Kongoli, C.E., and W.L. Bland. 2002. Influence of manure application on surface energy and snow cover: Field experiments. Journal of Environmental Quality 31:1166-1173.

Madison, F.W., K.A. Kelling, L. Massie, and L. Ward-Good. 1998. Guidelines for applying manure to cropland and pasture in Wisconsin. University of Wisconsin Extension Publications. Rep. A3392. 
McDowell, R., and A. Sharpley. 2002. Phosphorus transport in overland flow in response to position of manure application. Journal of Environmental Quality 31:217-227

Mickelson, S.K., P. Boyd, J.L. Baker, and S.I. Ahmed. 2001. Tillage and herbicide incorporation effects on residue cover, runoff, erosion, and herbicide loss. Soil \& Tillage Research 60:55-66.

Midwestern Regional Climate Center. 2007a. Historical Climate Data. Precipitation Summary. Plattesville, Wisconsin. http://mrcc.sws.uiuc.edu/climate_midwest/ historical/precip/wi/476646_psum.html.

Midwestern Regional Climate Center. 2007b. Historical Climate Data. Snowfall Summary. Plattesville, Wisconsin. http://mrcc.sws.uiuc.edu/climate_midwest/historical/ snow/wi/476646_ssum.html.

Milne,C.M.1976.Effect of a livestock wintering operation on a western mountain stream.Transactions of the American Society of Agricultural Engineers 19:749-752.

National Weather Service. 2007. Weather Data from Platteville, Wisconsin. http://www.ncdc.noaa.gov/oa/ ncdc.html.

Rabalais, N.N., R.E. Turner, and W.J. Wiseman, Jr. 2001. Hypoxia in the Gulf of Mexico.Journal of Environmental Quality 30:320-329.

Rabalais, N.N., R.E. Turner, Q. Dortch, D. Justic, V.J Bierman, Jr., and W.J. Wiseman, Jr. 2002. Nutrientenhanced productivity in the northern gulf of Mexico: Past, present and future. Hydrobiologia 475-476:39-63.

Srinivasan, M.S., R.B. Bryant, M.P. Callahan, and J.L. Weld. 2006. Manure management and nutrient loss under winter conditions: A literature review. Journal of Soil Water Conservation 61(4):200-209.

Stuntebeck, T.D., M.J. Komiskey, D.W. Owens, and D.W. Hall. 2008. Methods of data collection, sample processing, and data analysis for edge-of-field, streamgaging, subsurfacetile, and meteorological stations at Discovery Farms and Pioneer Farm in Wisconsin, 2001-7: U.S. Geological Survey Open-File Report 2008-1015.

USEPA (US Environmental Protection Agency). 1999. 1999 Update of ambient water quality criteria for ammonia. Rep. EPA-822-R-99-014.

Vadas, P.A., B.E. Haggard, and W.J. Gburek. 2005a. Predicting dissolved phosphorus in runoff from manured field plots. Journal of Environmental Quality 34:1347-1353.

Vadas, P.A., P.J.A. Kleinman, A.N. Sharpley, and B.L. Turner. 2005b. Relating soil phosphorus to dissolved phosphorus in runoff: A single extraction coefficient for water quality modeling. Journal of Environmental Quality 34:572-580.
Young, R.A., and R.F. Holt. 1977. Winter applied manure: Effects of annual runoff, erosion, and nutrient movement. Journal of Soil and Water Conservation 32(5):219-222.

Young, R.A., and C.K. Mutchler. 1976. Pollution potential of manure spread on frozen ground. Journal of Environmental Quality 5:174-179. 